Banco, Volume 1, November 2019

\title{
KONSEP KEADILAN DALAM ZAKAT PERTANIAN DAN ZAKAT PROFESI
}

\author{
Wahyuni \\ IAIN Parepare \\ Wahyuni21@iainparepare.ac.id \\ Rahman Ambo Masse \\ IAIN Parepare \\ rahmanambo@iainparepare.ac.id
}

Rukiah

IAIN Parepare

rukiah@iainparepare.ac.id

\begin{abstract}
One of the economic activities that is highly recommended by Islam is zakat. Al-Qur'an and hadith explain a lot about zakat, where zakat is very important and it is recommended to clean up wealth. In addition, the wealth spent on zakat will be a blessing, growth, increase and develop. The concept of fairness in collecting zakat includes several things, namely using the principle of justice in distribution. the assets issued fulfill the terms and conditions and then the zakat is given to groups which are entitled to receive.

This study aims to determine how the concept of justice in agricultural zakat and professional zakat, where this research uses a library approach and uses data collection methods and data processing validly.

Justice in agricultural zakat and professional zakat is justice based on two principles of justice (commutative justice and distributive justice). Agricultural Zakat is zakat of agricultural products such as cloves, cocoa, coffee, vegetables and can be stored for a long time removed from the harvest and has reached nishab which is 5\% if the crop is irrigated with irrigation equipment and if the crop is irrigated with rainfed then the zakat is $10 \%$ and does not have to pay zakat if it does not reach nishab. While professional zakat is zakat resulting from the thoughts, skills and expertise of a person obtained through higher education levels such as (advocates, lawyers, doctors, engineers, etc.) and has reached $2.5 \%$ of nishab, the proportion of which is equal to gold zakat and has also been equal reach haul. If the income does not reach nishab, it is not obligatory for it to pay zakat.
\end{abstract}

Keywords: Equality, Zakat, Agro, Profession 


\begin{abstract}
Abstrak
Salah satu kegiatan ekonomi yang sangat dianjurkan oleh Islam adalah zakat. Al-Qur'an dan hadist banyak menjelaskan tentang zakat, di mana zakat sangat penting dan dianjurkannya guna untuk membersihkan harta. Selain itu, harta yang dikeluarkan zakatnya akan menjadi berkah, tumbuh, bertambah dan berkembang. Konsep keadilan pengumpulan zakat itu meliputi beberapa yaitu menggunakan prinsip keadilan dalam distribusi. harta yang dikeluarkan memenuhi syarat dan ketentuan kemudian zakat tersebut diberikan kepada golongan-golongan yang berhak menerima.

Penelitian ini bertujuan untuk mengetahui begaimana konsep keadilan dalam zakat pertanian dan zakat profesi, di mana penelitian ini menggunakan pendekatan kepustakaan dan menggunakan metode pengumpulan data dan mengolah data secara valid.

Keadilan dalam zakat pertanian dan zakat profesi yaitu keadilan yang berlandaskan dua prinsip keadilan (keadilan komutatif dan keadilan distributif). Zakat pertanian ialah zakat hasil pertanian seperti cengkeh, coklat, kopi, sayur-sayuran dan dapat disimpan lama yang dikeluarkan dari hasil panen dan telah mencapai nishab yaitu $5 \%$ jika tanaman itu diairi dengan alat pengairan dan jika tanaman itu diairi dengan tadah hujan maka zakatnya $10 \%$ dan tidak wajib dikeluarkan zakatnya apabila tidak mencapai nishab. Sedangkan zakat profesi ialah zakat hasil dari pemikiran, keterampilan dan keahlian seseorang yang didapat melalui jenjang pendidikan tinggi seperti (advokat, pengacara, dokter, insinyur, dll sejenisnya) dan telah mencapai nishab yaitu 2,5\% yang nishabnya disamakan dengan zakat emas dan juga telah mencapai haul. Apabila pendapatannya tidak mencapai nishab maka tidak wajib atasnya mengeluarkan zakat.
\end{abstract}

Kata kunci: Keadilan, Zakat Peranian dan Zakat Profesi

\title{
A. Pendahuluan
}

Islam sebagai agama wahyu yang dirisalahkan sejak manusia pertama, Nabi Adam. Kemudian dilanjutkan dan disempurnakan melalui syariat Allah Swt. dengan perantaraan Nabi Muhammad Saw. Dengan demikian, ajaran Islam sudah diakui sebagai sumber dan pedoman dalam bertingkah laku. Karena tingkah laku ekonomi itu bagian dari ulah manusia, maka ilmu dan aktifitas ekonomi haruslah berada di dalam ajaran Islam. Keunikan pendekatan Islam terlatak pada sistem nilai yang mewarnai tingkah laku ekonomi. Ilmu ekonomi adalah satu bagain saja dari ajaran Islam, sehingga sistem ekonomi dengan sendirinya tidak mungkin dapat dipisahkan dari supra-sistemnya, yaitu Islam.

Dalam Islam, sistem ekonomi paling tidak menampilkan dua sasaran pencapaian sosio-ekonomi, yaitu pertama, hendaknya mendekatkan manusia pada kehidupan yang penuh harga diri, baik spiritual maupun material bagi seluruh warga masyarakat. Material tidak boleh mendominasi spiritual, begitupula sebaliknya. Islam lebih menekankan pada sisi keseimbangan di antara keduanya. Kedua, hendaknya membawa kepada keadilan distributif dan mengurangi melebarnya kesenjangan antara kaya dan miskin. Jika terjadi kesenjangan antara kaya dan miskin, maka dampak buruknya sangat basar terhadap kehidupan bermasyarakat.] Karenanya, setiap kegiatan ekonomi dalam Islam selalu berusaha untuk mencegah hal-hal yang kegiatannya dengan penyebab kemiskinan ${ }^{1}$.

Zakat adalah satu dari lima sendi pokok ajaran Islam yang menyangkut sosial ekonomi dalam rangka mewujutkan kesejahteraan dan keadilan sosial yang merata bagi umat manusia. Dilihat dari segi kategorisasi dalam ajaran Islam atau dalam jajaran lima perangkat rukun Islam, orang cenderung memasukkan zakat ke dalam bidang ibadah mahdah bidang yang goiru ma'qul al-ma'na atau unreasonable, bidang di mana akal pikiran tidak memegang peran penting. Ijtihad dan qiyas tidak berlaku karena bersifat dogmatikal.

Sesuai dengan Dasar Negara Republik Indonesia yaitu Pancasila dan sesuai dengan ketentuan pasal 29 ayat 2 Undang-undang Dasar 1945 yakni "Negara menjamin tiap-tiap penduduk untuk memeluk agamanya masing-

${ }^{1}$ Muhammad A. Al-Buraey, Administratif Development: an Islamic Perspektif (Ahmad Nasir Budiman, Penerjemah), Islam: Landasan Alternatif Administrasi Pembangunan (Jakarta: Rajawali, 1986), h. 205-206. 
masing dan untuk beribadat menurut agama dan kepercayaan itu", maka pemerintah mempunyai tugas dan kewajiban untuk memberikan bimbingan serta bantuan guna memperlancar usaha pembangunan agama sesuai dengan ajaran agama masing-masing termasuk pengelolaan zakat².

Allah Swt., telah menentukan jenis dari harta yang harus dikeluarkan zakat dan memilih di antaranya yang terbagus dan terbaik. Allah mewajibkan zakat pada emas, perak, dan tembaga, Allah juga mewajibkan zakat pada binatang ternak seperti unta, sapi, dan kambing bukan pada kedelai, dan binatang-bianatang yang sedikit manfaatnya serta mudah didapat, seperti ayam, kelinci dan juga burung. Allah mewajibkan zakat pada tanamantanaman yang mempunyai jenis terbaik seperti biji-bijian dan buah-buahan bukan pada kacang-kacangan, sayursayuran dan jamur ${ }^{3}$.

Dapat dipahami bahwa zakat ialah kewajiban yang dibebankan oleh Allah Swt. kepada setiap orang Islam untuk mengeluarkan sebagian hartanya sesuai dengan ketentuan-ketentuan yang telah digariskan oleh al-Qur'an dan sunnah baik syarat-syaratnya ataupun jumlahnya. Ketentuan-ketentuan dan syarat-syarat ialah nishab atau besar harta yang harus dikelurkan. Ajaran tentang zakat ini dalam Islam merupakan hal yang amat penting. Pada zaman yang serba modern dan instan seperti zaman sekarang, banyak manusia mendapatkan penghasilan yang begitu besar dengan bermodalkan ilmu pengetahuan yang didapat dari jenjang pendidikan formal.

Pendidikan yang manusia dapat dari sistem pendidikan yang diprogramkan oleh pemerintah, sedikit banyaknya dapat menimbulkan penghasilan-penghasilan yang luar biasa besarnya dibandingkan dengan hasil pertanian, peternakan dan perkebunan. Memang dalam satu kali panen dengan jangka satu tahun, dari tiga tiang tersebut bisa menghasilkan keuangan besar, namun bagi orang yang berpendidikan penghasilan keuangan satu bulan kadang sama dengan penghasilan panen dari tiga bidang tersebut. Karena dengan pendidikan yang didapat oleh manusia, ia bisa memiliki profesi yang sesuai dari bidang pendidikan yang telah ia perdalami.

Zakat profesi yang telah menjamur di zaman modern ini dan pada zaman Rasulullah Saw. hanya membahas tentang sumber pendapatan dari pertanian, peternakan, dan perdagangan. Sedangkan sumber pendapatan profesi tidak banyak dikenal di masa generasi terdahulu. Namun bukan berarti pendapatan dari hasil profesi terbebas dari zakat, karena zakat secara hakikatnya adalah pungutan terhadap kekayaaan dari golongan yang memilki kelebihan harta untuk diberikan kepada golongan yang membutuhkan.

Allah Swt., berfirman dalam Q.S. al-Baqarah/2:267.

Terjemahnya :

"Hai orang-orang yang beriman, nafkabkeanlah (di jalan Allab) sebagian dari basil usahamu yang baik-baik dan sebagian dari apa yang kamu keluarkan dari bumi untuk kamu miliki yang buruk-buruk lalu kamu menafkabkan daripadanya. Padahal kamu sendiri tidak mau mengambilnya melainkan dengan memincingkan mata terhadapnya. Dan ketahuilah bahwa Allah maha kaya lagi maha terpuji”.

Pada umumnya, nishab zakat pertanian adalah 5 wasaq atau setara dengan $1.350 \mathrm{~kg}$ gabah atau $750 \mathrm{~kg}$ beras sedangkan zakat profesi nishabnya dipersamakan dengan zakat emas senilai $85 \mathrm{~kg}$ dengan besar zakat 2,5\% yang dibayar pertahun. Disebabkan adanya sistem penarikan zakat pertanian dan zakat profesi tersebut, peneliti tertarik untuk melakukan penelitian guna menguraikan Konsep Keadilan Dalam Zakat Pertanian Dan Zakat Profesi ${ }^{4}$.

${ }^{2}$ Mughni Labib, Korelasi Pengelolaan Zakat Menurut UU dan Hukum Islam, www.darussaadah.or.id (diakses tanggal 24 februari 2017).

${ }^{3}$ Ahmad Al-Hamid Mahmud, Ekonomi Zakat (Jakarta: Raja grafindo Persada), h. 6.

${ }^{4}$ Sayyid Sabiq, Fiqh Sunnah (Jakarta: Pena Pudi Aksara, 2009), h. 644.

Banco, Volume 1, November 2019 


\section{B. Diskusi dan Pembahasan}

\section{Gambaran Umum Zakat Profesi}

Profesi berasal dari kata bahasa Inggris profesion. bahasa latin professus yang berartikan mampu atau ahli dalam suatu pekerjaan suatu profesi iyalah suatu pekerjaan yang menuntut pendidikan tinggi, biasanya meliputi pekerjaan mental yang ditunjang oleh kepribadiaan serta sikap professional.

Menurut Peter Jarvis, profesi merupakan suatu pekerjaan yang didasarkan pada studi intelektual dan latihan yang khusus, tujuannya ialah untuk menyediakan pelayanan keterampilan terhadap yang lain dengan bayaran maupun upah tertentu. Sedangkan menurut Dedi Supriadi profesi merupakan pekerjaan atau jabatan yang menuntut suatu keahlian, tanggung jawab serta kesetian terhadap profesi.

Profesi merupakan suatu pekerjaan, jabatan yang menuntut suatu keahlian yang didapat melalui pendidikan serta latihan tertentu, menuntut persyaratan khusus, yang memiliki tanggung jawab serta kode etik tertentu.

Zakat adalah rukun yang bercorak sosial-ekonomi dari lima rukun Islam dengan zakat di samping ikrar tauhid (syahadat) dan shalat. Zakat profesi adalah istilah yang muncul pada dewasa ini. Adapun istilah ulama' salaf bagi zakat profesi biasanya disebut dengan al-mal al-mustafad, yang termasuk dalam kategori zakat al-mal mustafad adalah pendapatan yang dihasilkan dari profesi non zakat yang dijalani, seperti gaji pegawai negeri/swasta, konsultan, dokter dan lain-lain, atau rezeki yang dihasilkan secara tidak terduga seperti undian, kuis berhadiah (yang tidak mengandung unsur judi) dan lain-lain.

Profesi yang menghasilkan uang ada dua macam. Pertama adalah profesi yang dikerjakan sendiri tanpa tergantung kepada orang lain, berkat kecekatan tangan ataupun otak. Profesi yang diperoleh dengan cara ini merupakan penghasilan professional, seperti penghasilan seorang dokter, insinyur, advokat, seniman, penjahit, tukang kayu. Profesi yang kedua adalah pekrjaan yang dikerjakan seseorang buat pihak lain, baik pemerintah, perusahaan, maupun perorangan dengan memperoleh upah, yang diberikan dengan tangan, otak ataupun kedua-duanya. Penghasilan dari pekerjaan ini berupa gaji, upah ataupun honorarium.

Zakat profesi merupakan hal baru di dunia Islam yang muncul belakangan ini, pro dan kontra mewarnai perdebatan mengenai hal tersebut. Mayoritas ulama empat madzhab tidak mewajibkan zakat penghasilan pada saat menerima kecuali sudah mencapai nishab dan sudah sampai setahun (haul), namun para ulama mutaakhirin seperti Al-Qardhawi dan Wahbah Az-Zuhaili, menegaskan bahwa zakat penghasilan itu hukumnya wajib pada saat memperolehnya meskipun belum mencapai satu tahun. Hal ini mengacu pada pendapat sebagian dari sahabat yaitu Ibnu Abbas, Ibnu Mas'ud dan Mu'awiyah, Tabiin Az-Zuhri, Al-Hasan Al-Bashri, dan Makhul juga pendapat Umar bin Abdul Aziz dan beberapa ulama fiqh lainnya.

Adapun kewajiban zakatnya adalah 2,5\%, berdasarkan keumuman nhas yang mewajibkan zakat uang, baik sudah mencapai satu haul atau ketika menerimanya. Jika sudah dikeluarkan zakatnya pada saat menerimanya, maka ia wajib mengeluarkan zakat lagi pada akhir tahun. Demikian ada kesamaan antara pegawai yang menerima gaji secara rutin dengan petani yang wajib mengeluarkan zakat pada saat panen, tanpa ada perhitungan haul.

Pendapat Yusuf Al-Qardhawi tentang zakat profesi yaitu bahwa penghasilan atau profesi wajib dikeluarkan zakatnya pada saat diterima jika sampai pada nishab setelah dikurangi hutang dan zakat profesi bisa dikeluarkan harian, mingguan, atau bulanan. Sebagaimana kita ketahui, bahwa diantara syarat-syarat harta yang wajib dizakati, selain zakat pertanian dan barang tambang (rikaz), harus ada masa kepemilikan selama satu tahun, yang dikenal dengan istilah haul. Sementara Al-Qardhawi dan juga para pendukung zakat profesi berkeinginan agar gaji dan pemasukan dari berbagai profesi itu wajib dibayarkan meski belum dimiliki selama satu haul. 
Abdul Wahab adalah seorang ulama besar di Mesir (1888-1906), dikenal sebagai ahli hadits, ahli ushul fiqih dan juga ahli fiqih. Salah satu karya utama beliau adalah kitab Ushul Fiqih, Ahkam Al-Ahwal Asy-Syakhshiyah, Al-Waqfu wa Al-Mawarits, As-Siyasah Asy-Syar'iyah, dan juga dalam masalah tafsir, Nur min Al-Islam. Saya memasukkan beliau di kalangan pendukung zakat profesi dengan alasan beliau adalah orang yang memberi inspirasi awal kepada Dr. Yusuf Al-Qardhawi tentang pemikiran dan ide dicetuskannya zakat profesi. Namun anehnya, kalau kita rujuk langsung kepada pendapat beliau, sebenarnya beliau lebih tepat didudukkan sebagai orang yang tidak sejalan dengan zakat profesi. Dalam kuliah yang beliau sampaikan tentang zakat, disebutkan bahwa zakat profesi itu wajib, namun harus memenuhi syarat haul dan nishab dulu. Berikut kutipannya

"Sedangkan penghasilan kerja dan profesi diambil zakatnya apabila telah dimiliki selama setahun dan telah mencapai nishab."

Dalam fatwanya, Muhammad Al-Ghazali mengatakan bahwa orang yang penghasilannya di atas petani yang terkena kewajiban zakat, maka dia pun wajib berzakat. Maka doker, pengacara, insinyur, produsen, pegawai dan sejenisnya diwajibkan untuk mengeluarkan zakat dari harta mereka yang terhitung besar itu.

Berdasarkan pertimbangan bahwa kedudukan hukum zakat penghasilan, baik penghasilan rutin seprti gaji pegawai atau karyawan atau penghasilan pejabat negara, maupun penghasilan tidak rutin seprti dokter, pengacara, konsultan, penceramah, dan sejenisnya, serta penghasilan yang diperoleh dari pekerjaan bebas lainnya, masih sering ditanyakan oleh umat Islam Indonesia, Majelis Ulama Indonesia mengeluarkan Fatwa Nomor 3 Tahun 2003 tanggal 06 R. akhir 1424 H/07 Juni 2003 M tentang zakat penghasilan.

Dalam fatwa ini, MUI mendasarkan pada petunjuk dalam al-Qur'an juga hidist nabi sebagai berikut:

"Hai orang yang beriman, nafkabkanlah sebagian dari hasil usahamu yang baik-baik dan sebagian dari apa yang kami keluarkan dari bumi untuk kamu..." (Q.S. Al-Baqarah/2: 267).

"...Dan mereka bertanya kepada apa yang mereka nafkabkan. Katakanlab: "Yang lebih dari keprluan”...”(Q.S. Al-Baqarah/2: 219).

"Ambillah zakat dari sebagian harta mereka, dengan zakat ini kamu membersibkan dan mensucikan mereka..." (Q.S. at-Taubab/9: 103).

'Diriwayatkan secara mafru' hadist Ibnu Umar, dari Nabi Saw. beliau bersabda, "tidak ada zakat pada harta sampai berputar satu tabun". (HR)

Dari Abu Hurairab r.a. Rasulullah Saw. bersabda "tidak ada zakat atas orang muslim terbadap hamba sahaya dan keduanya". (HR. Muslim).

Imam Nawawi berkata "Hadist ini adalah dalil bahwa harta qinyah (harta yang digunakan untuk keperluan pemakaian, bukan untuk dikembangkan) tidak dikenakan rakat."

Dari bakim bin bizam r.a., dari Nabi Saw. beliau bersabda: "Tangan atas lebih baik dari pada tangan bawah. Mulailah (dalam membelanjakan harta) dengan orang yang menjadi tanggung jawabmu. Sedekah paling baik adalah yang dikeluarkan dari kelebihan kebutuban. Barang siapa berusaha menjaga diri (dari keburukan), Allah Swt. akan menjaganya. Barang siapa berusaha mencukupi diri, Allah Swt. akan memberinya kecukupan." (HR. bukhari). 


\section{Wahyuni, Rahman Ambo Masse dan Rukiah}

Dari abu burairah r.a., Rasulullah Saw. bersabda: "Sedekah hanyalah dikeluarkan dari kelebihan atau kebutuhan. Tangan atas lebih baik dari pada tangan bawah. Mulailah (dalam membelanjakan harta) dengan orang yang menjadi tanggung jawabmu". (HR. Abmad). ${ }^{5}$

Dalam penarikan zakat profesi ada beberapa hal yang harus diperhatikan sesuai dengan ketentuan yang sudah ada sebelumnya yaitu: syarat-syarat zakat profesi dan nishab kadar dan waktu pengeluarannya.

Adapun beberapa syarat yang harus dipenuhi dalam masalah kewajiban zakat. Syarat tersebut berkaitan dengan muzakki (orang yang mengeluarkan zakat) dan berkaitan dengan harta.

Syarat pertama, berkaitan dengan muqakki: Islam dan merdeka. Adapun anak kecil dan orang gila, jika memiliki harta dan memenuhi syarat-syaratnya itu masih kenai zakat yang nanti akan dikeluarkan oleh walinya. Pendapat ini adalah pendapat terkuat dan dipilih oleh mayoritas ulama.

Syarat kedua, berkaitan dengan harta yang dikeluarkan:

a. Harta tersebut dimilki secara sempurna

b. Harta tersebut adalah harta yang berkembang

c. Harta tersebut telah mencapai nishab

d. Telah mencapai haul (harta tersebut bertahan selama setahun)

e. Harta tersebut merupakan kelebihan dari kebutuhan pokok.

Sudah kita ketahui, bahwa Islam tidak mewajibkan zakat atas seluruh harta benda, sedikit atau banyak, akan tetapi mewajibkan zakat harta benda yang mencapai nishab, bersih dari hutang, lebih dari kebutuhan pokok pemiliknya. Hal ini menetapkan siapa yang tergolong orang kaya yang wajib zakat karena zakat hanya dipungut dari orang-orang kaya tersebut.

Allah Swt. berfirman dalam Q.S. Al-Baqarah/2: 219.

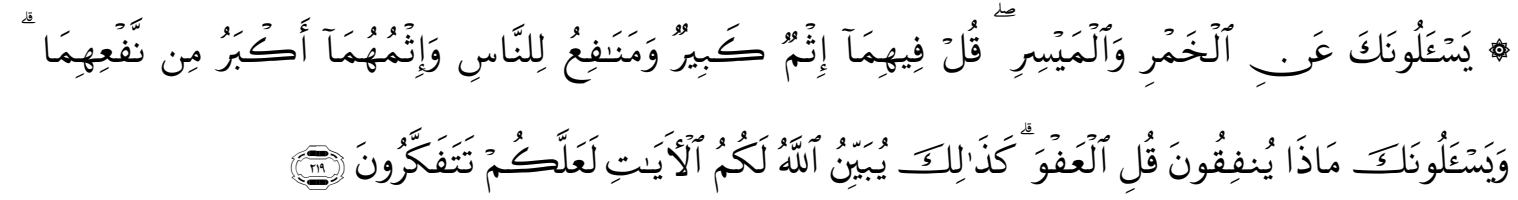

Terjemahnya:

Mereka bertanya kepadamu tentang khamar dan judi. Katakanlah: "Pada keduanya terdapat dosa yang besar dan beberapa manfaat bagi manusia, tetapi dosa keduanya lebih besar dari manfaatnya". dan mereka bertanya kepadamu apa yang mereka nafkeahkan. Katakanlab: "yang lebih dari keperluan." Demikianlah Allah menerangkan ayat-ayat-Nya kepadamu supaya kamu berfikir. ${ }^{6}$

Rasulullah Saw. bersabada: "Kewajiban zakat hanya bagi orang kaya." "Mulailah dari orang yang menjadi tanggunganmu. "Hal itu sudah ditegaskan dalam syarat-syarat kekayaan yang wajib dizakati dan zakat wajib dikeluarkan apabila sudah mencapai nishab harta kekayaan itu.

Menurut ilmu ushul fiqh (metodelogi hukum Islam), untuk menyelesaikan kasus-kasus yang tidak diatur oleh nash (al-Qur'an dan sunnah) secara jelas ini, dapat diselesaikan dengan jalan mengembalikan persoalan tersbut kepada al-Qur'an dan Sunnah itu sendiri. Pengembalian kepada dua sumber hukum

5http://tunas63.wordpress.com. Fatwa MUI Tentang Zakat Penghasilan.Diunduh pada tanggal 15 juni 2017. 
itu dapat dilakukan dengan dua cara, yakni dengan perluasan makna lafaz dan dengan jalan qias (analogi). ${ }^{7}$

Khusus mengenai zakat profesi ini, hukumnya dapat ditetapkan berdasarkan perluasan cakupan makna lafaz.

Allah Swt., dalam Q.S. Al-Baqarah/2: 267.

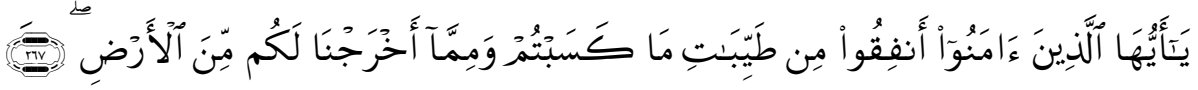

Terjemahnya:

"Hai orang-orang yang beriman, nafkabkanlah sebagian dari hasil usabamu yang baik-baik. dan sebagian dari apa yang telah kami keluarkan dari bumi untuk kamu."

Apa saja yang kamu usahakan dalam ayat diatas pada dasarnya bersifat umum, namun ulama kemudian membatasi pengertiannya terhadap beberapa jenis usaha atau harta yang wajib dizakatkan, yakni harta perdagangan, emas dan perak, hasil pertanian dan peternakan. Pengkhususan terhadap beberapa bentuk usaha dan harta ini tertentu saja membatasi cakupan lafaz umum pada ayat tersebut sehingga tidak mencapai selain yang disebutkan tersebut. Untuk menetapkan hukum zakat profesi, lafaz umum tersebut mestilah dikembalikan kepada keumumannya sehingga cakupannya meluas meliputi segala usaha yang halal yang menghasilkan uang atau kekayaan bagi setiap muslim, dan pada dasarnya hukum zakat profesi itu wajib dengan berdasarkan keumuman ayat diatas.

Dasar hukum kedua mengenai zakat profesi ini adalah qias atau menyamakan zakat profesi dengan zakat-zakat yang lain separti zakat hasil pertanian dan zakat emas dan perak. Allah Swt. telah mewajibkan untuk mengeluarkan zakat dari hasil pertaniannya bila mencapai nishab 5 wasaq $(750 \% \mathrm{~kg}$ beras) sejumlah 5 atau 10\%. Logikanya, bila untuk hasil pertanian saja sudah wajib zakat, dan tentu untuk profesi-profesi tertentu yang menghasilkan uang jauh melebihi pendapatan petani, juga wajib dikeluarkan zakatnya.

Sedangkan ulama-ulama salaf berpendapat bahwa harta penghasilan wajib dikeluarkan zakatnya. Ada dua cara dalam mengeluarkan zakatnya, yaitu:

a. Az-Zuhri berpendapat bahwa bila seseorang perpenghasilan dan ingin membelanjakannya sebelum bulan wajib zakatnya datang, maka hendaklah ia segera mengeluarkan zakat itu terlebih dahulu dari membelanjakannya, dan bila tidak ingin membelanjakannya maka hendaklah ia mengeluarkan zakatnya bersamaan dengan kekayaannya yang lain-lainnya. Pendapat yang sama dikeluarkan oleh Auza'I tentang seseorang yang menjual hambanya atau rumahnya, bahwa ia wajib mengeluarkan zakat sesudah menerima uang penjualan di tangannya, kecuali bila ia mempunyai bulan tertentu untuk mengeluarkan zakat, maka hendaknya ia mengeluarkan zakat uang penjualan tersebut bersamaan dengan hartanya yang lain tersebut. Ini berarti bahwa bila seseorang mempunyai harta yang sebelumnya harus dikeluarkan zakatnya dan mempunyai masa tahun tertentu maka hendaknya ia mengendurkan pengeluaran zakat penghasilannya itu bersamaan dengan hartanya yang lain, kecuali bila ia kuatir penghasilannya itu terbelanjakan sebelum datang masa tahunnya tersebut yang dalam hal ini ia hendaknya segara mengeluarkan zakatnya.

b. Makhul berpendapat bahwa bila seseorang harus mengeluarkan zakat pada bulan tertentu kemudian memperoleh uang tetapi kemudian dibelanjakannya, maka uang itu tidak wajib zakat, yang wajib zakat hanya uang yang sudah datang bulan untuk mengeluarkan zakat pada bulan untuk mengeluarkan zakatnya itu. Akan tetapi jika ia tidak mengeluarkan zakat pada bulan tertentu

7https://sadudinm.wordpress.com. Diunduh pada tanggal 12 Juni 2017.

Banco, Volume 1, November 2019 


\section{Wahyuni, Rahman Ambo Masse dan Rukiah}

kemudian ia memeproleh uang, maka ia harus mengeluarkan zakatnya pada waktu uang tadi diperoleh. Pendapat itu dengan demikian memberikan keistimewaan kepada orang-orang yang mempunyai uang yang harus dikeluarkan zakatnya pada bulan tertentu, dan tidak memeberikan keistimewaan kepada orang yang tidak mempunyai uang. Yang dimaksud adalah, memberikan keinginan kepada orang yang mempunyai kekayaan lain dan memeberi beban kepada orang yang tidak mempunyai kekayaan selain penghasilan.

Menurut Yusuf Qardhawi dari pendapat tersebut, yang lebih kuat adalah pendapat yang mengatakan bahwa penghasilan yang mencapai nishab wajib diambil zakatnya, sebagaimana yang dikatakan oleh Zuhri dan Auza'I, baik dengan mengeluarkan zakatnya begitu juga dengan yang diterima, ini khususnya bagi mereka yang tidak mempunyai kekayaan lain yang bermasa wajib zakat tertentu ataupun dengan mengundurkan pengeluaran zakat sampai batas setahun bersamaan dengan kekayaannya yang lain bila ia tidak khawatir akan membelanjakannya. Akan tetapi, bila khawatir penghasilan itu akan terbelanjakan olehnya, maka ia harus mengeluarkan zakatnya segera, dan juga sekalipun ia membelanjakan penghasilannya itu, maka zakatnya tetap menjadi tanggung jawabnya. Bila tidak mencapi nishab, maka zakatnya diambil dari pendapat makhul yaitu bahwa kekayaan yang sudah sampai bulan pengeluaran zakat maka harus dikeluarkan zakatnya. Kekayaan yang dibelanjakan untuk nafkah sendiri dan tanggungannya tidak diambil zakatnya, dan bila ia tidak mempunyai hata lain maka ia harus mengeluarkan zakatnya pada waktu tertentu. Sedangkan penghasilan yang tidak mencapai nishab, maka tidak wajib zakat sampai mencapai nishab bersama dengan kekayaan lain yang harus dikeluarkan zakatnya pada waktu nishab itu dan masa sampainya dimulai dari nishabtertentu.

Perlu diketahui bahwa kawajiban zakat atas gaji, upah, dan sejenisnya profesi bahwa zakat tetentu hanya diambil dari pendapatan bersih. Pengambilan dari pendapatan atau gaji bersih dimasudkan supaya hutang bisa dibayar bila ada dan rendah kehidupan seseorang merupakan kebutuhan pokok seseorang, sedangkan zakat diwajibkan atas jumlah sampai nishab yang sudah melebihi kebutuhan pokok. Juga harus dikeluarkan biaya dan ongkos-ongkos untuk melakukan pekerjaan tersebut. Berdasarkan hal itu, maka sisa gaji dan pendapatan setahun wajib zakat bila mencapi nishab uang, sedangkan gaji dan upah setahun yang tidak mencapai nishab uang setahun setelah biaya-biaya kebutuhan dikeluarkan misalnya gaji pekerja-pekerja dan pegawai-pegawai kecil maka tidak wajib dikenakan zakat.

Majelis ulama Indonesia mengeluarkan fatwa Nomor 3 Tahun 2003 tanggal 06 R. akhir 1424 H/07 Juni 2003 M Tentang Zakat Penghasilan. Dalam fatwa ini terdapat 4 hal yang telah ditetapkan yaitu (1) Ketentuan Umum: dalam fatwa ini, yang dimaksud dengan "penghasilan" adalah setiap pendapatan seperti gaji, honorarium, upah, jasa, dan lain-lain yang diperoleh dengan cara halal, baik rutin seperti pejabat Negara, pegawai atau karyawan, maupun tidak rutinseperti dokter, pengacara, konsultan, dan sejenisnya, serta pendapatan yang diperoleh dari pekerjaan bebas lainnya. (2) Hukum: semua bentuk penghasilan halal wajib dikeluarkan zakatnya dengan syarat telah mencapai nishab dalam satu tahun, yakni senilai emas 85 gram. (3) Kadar Zakat: kadar zakat penghasilan adalah 2,5\% (4) waktu pengeluaran zakat: Zakat penghasilan dapat dikeluarkan pada saat menerima jika sudah cukup nishab dan jika tidak mencapai nishab, maka semua penghasilan dikumpulkan selama satu tahun, kemudian zakat dikeluarkan jika penghasilan bersihnya cukup nishab.

Mengenai nishab, kadar dan waktu pengeluarannya zakat profesi sangat bergantung pada qiyas (analogi), yang dilakukan oleh para ulama melalui ijtihadnya. Menurut pendapat yang terkuat, nishab zakat profesi ini adalah 85 gram emas.Adapun jumlah zakat yang wajib dikluarkan adalah sebesar 2,5\% dan haul (jatuh tempo) zakatnya dikeluarkan langsung saat menerima atau setelah diperhitungkan 
selama kurung waktu tertentu, misalnya setahun, bergantung pada jenis pekerjaan dan cara termudah untuk menghitunngnya. ${ }^{8}$

Dalam Undang-undang No. 38 Tahun 1999 tentang Pengelolaan Zakat, telah diatur bahwa penghasilan dari kegiatan atau pekerjaan suatu profesi berupa gaji, upah, honorarium, dan lain sebagainya nishabnya dipersamakan dengan zakat emas, yaitu senilai 85 gram dengan besar zakatnya adalah 2,5 persen dan dibayarkan pertahun.

Sebagi contoh, seandainya perhitungan zakat penghasilan disetarakan dengan harga emas, yaitu sebesar Rp. 530.000,- per gram emas kadar 95, maka nishabnya 85 gram x Rp. 530.000,- $=45.050 .000-$ , oleh karenanya, apabila seorang pegawai atau pekerja professional mempunyai penghasilan sebesar Rp. 12. 000.000,- per tahun maka zakatnya sebesar Rp. 300.000,- per tahun, dan biasa dibayarkan setiap bulan sebesar Rp. 25.000,-.

Dalam buku Figh Zakat karya Yusuf Al-Qardhawi bab zakat profesi atau penghasilan, dijelaskan tentang cara mengeluarkan zakat penghasilan dan diklasifikasikan dalam tiga cara yaitu:

a. Pengeluaran bruto, yaitu mengeluarkan zakat penghasilan kotor. Artinya zakat penghasilan yang mencapai nishab 85 gr emas dalam jumlah setahun, dikeluarkan 2,5\% langsung ketika menerima sebelum dikurangi apapun. Jadi kalau dapat gaji atau honor dan penghasilan lainnya dalam sebulan mencapai 2 juta rupiah x 12 bulan $=24$ juta, berarti dikeluarkan langsung $2,5 \%$ dari 2 juta tiap bulan $=50$ ribu atau dibayar di akhir tahun $=600$ ribu. Hal ini juga berdasarkan pendapat AzZuhri dan 'Auza'I beliau menjelaskan: "bila seorang memperoleh penghasilan dan ingin membelanjakannya sebelum bulan wajib zakat datang, maka hendaknya ia segera mengeluarkan zakat itu terlebih dahulu dari membelanjakannya." (Ibnu Abi Syaibah, Al-Mushannif, 4/30). Juga menqiyaskan tanpa dikurangi apapun, seperti zakat ternak, emas perak, ma'dan dan rikaz.

b. Dipotong operasional kerja, yaitu setelah menerima penghasilan gaji atau honor yang mencapai nishab, maka dipotong dahulu dengan biaya operasionak kerja. Contohnya seorang mendapat gaji 2 juta rupiah sebulan, dikurangi biaya transport dan komsumsi haran di tempat kerja sebanyak 500.000,- sisanya 1.500.000,- maka zakatnya dikeluarkan 2,5 dari 1.500.000,- $=37.500$,- Hal ini dianalogikan dengan zakat hasil bumi dan kurma serta sejenisnya, bahwa biaya dikeluarkan lebih dahulu baru zakat dikeluarkan dari sisanya itu adalah pendapat Imam Atho' dan lain-lain.Dari zakat hasil bumi ada perbedaan persentase zakat antara yang diari dengan hujan yaitu $10 \%$ dan melalui irigasi $5 \%$.

c. Pengeluaran neto atau zakat bersih, yaitu mengeluarkan zakat dari harta yang bersih mencapai nishab setelah dikurangi untuk kebutuhan pokok sehari-hari, baik pangan, papan, hutang, dan kebutuhan pokok lainnya untuk keperluan dirinya, keluarga dan yang menjadi tanggungannya. Jika penghasilan setelah dikurangi kebutuhan pokok masih mencapai nishab tidak wajib zakat, karena dia bukan termasuk muzakki (orang yang wajib zakat) bahkan menjadi mustabiq (orang yang menerima zakat) karena sudah menjadi miskin dengan tidak cukupnya penghasilan terhadap kebutuhan pokok sehari-hari. Hal ini berdasarkan hadist riwayat Imam Al-bukhari dari Hakim bin Hizam bahwa Rasulullah Saw., bersabda: “...dan paling baiknya zakat itu dikeluarkan dari kelebihan kebutuban...."

\section{Asas Keadilan Penarikan Zakat Profesi}

Zakat profesi sebenarnya bukanlah zakat yang disepakati keberadaannya oleh semua ulama. Hal ini lantaran di masa lalu, para ulama tidak memandang profesi dan gaji seseorang sebagai bagian dari

${ }^{8}$ http://tunas 63.wordpress.com.Fatwa MUI Tentang Zakat Penghasilan.Diunduh pada tanggal 24 Juli 2017.

${ }^{9}$ Didin Hafidhuddin, Panduan Praktis Tentang Zakat, Infaq, Sedeqah (Jakarta: Gema Insani Press, 2002), 104.

Banco, Volume 1, November 2019 


\section{Wahyuni, Rahman Ambo Masse dan Rukiah}

bentuk kekayaan yang mewajibkan zakat. Karena umumnya di masa lalu, belum ada sistem kepegawaian yang bergaji tinggi, kalau pun ada orang yang bekerja dan mendapat gaji, umumnya merupakan upah sebagai pembantu dan pekerjaan-pekerjaan sejenis yang rendah upahnya. Di masa lalu, orang yang kaya identik dengan peternak, petani, pedagang, pemilik emas dan lainnya. Sedangkan seseorang yang bekerja pada orang lain dan menerima upah, umumnya hanyalah pembantu dengan gaji seadanya. Sehingga di masa itu tidak terbayangkan bila ada seorang pekerja yang menerima upah bisa menjadi seorang kaya.

Namun zaman memang telah berubah, orang kaya tidak lagi selalu identik dengan petani, peternak dan pedagang belaka. Di masa sekarang ini, profesi jenis tertentu akan memberikan nilai nominal pemasukan yang puluhan bahkan ratusan kali dari hasil yang diterima seorang petani kecil. Sebagai ilustrasi, profesi seperti lawyer (pengacara) kondang di masa kini bisa dengan sangat cepatnya memberikan pemasukan ratusan bahkan milyaran rupiah, cukup dengan sekali kontrak. Demikian juga dengan artis atau pemain film kelas atas. Nilai kontraknya bisa untuk membeli tanah satu desa. Seorang pemain sepak bola di klub-klub Eropa akan menerima bayaran sangat mahal dari klub yang mengontraknya, untuk satu masa waktu tertentu, bahkan seorang dokter spesialis dalam satu hari bisa menangani berpuluh pasien dengan nilai total pemasukan yang lumayan besar. Sulit untuk mengatakan bahwa orang-orang dengan pemasukan uang sebesar itu bebas tidak bayar zakat, sementara petani dan peternak di desa-desa miskin yang tertinggal justru wajib bayar zakat. Maka wajah keadilan syariat Islam tidak nampak.

Dapat disimpulkan bahwa keadilan dalam zakat profesi terdapat pada dua asas keadilan yang dijadikan rujukan dalam penetapan keadilan yaitu: Pertama, asas pemerataan dalam teori keadilan komulatif di mana yang dimaksud keadilan komulatif yaitu keadilan yang memberikan kepada masingmasing orang apa yang menjadi bagiannya, di mana yang diutamakan adalah objek tertentu yang merupakan hak dari seseorang. Keadilan komutatif berkenaan dengan hubungan antarorang/antarindividu. Di sini ditekankan agar prestasi sama nilainya dengan kontra prestasi. Kedua. Keadilan distributif adalah keadilan yang memberikan kepada masing-masing orang apa yang menjadi haknya, di mana yang menjadi subjek hak adalah individu, sedangkan subjek kewajiban adalah masyarakat. Keadilan distributif berkenaan dengan hubungan antara individu dan masyarakat/negara. Di sini yang ditekankan bukan asas kesamaan/kesetaraan (prestasi sama dengan kontra prestasi). Melainkan, yang ditekankan adalah asas proporsionalitas atau kesebandingan berdasarkan kecakapan, jasa, atau kebutuhan. Keadilan jenis ini berkenaan dengan benda kemasyarakatan seperti jabatan, barang, kehormatan, kebebasan, dan hak-hak.

Sistem penarikan zakat hasil profesi yaitu hasil yang didapat dari pemikiran dan keahlian seseorang serta melalui jenjang pendidikan atau pengetahuan yang tinggi seperti, Advokad, dokter, pengacara, insinyur dan sejenisnya. Dan sistem penarikan zakat hasil profesi meliputi: Pendapatan yang diperoleh melebihi dari kebutuhan pokok, mencapai nishab atau kadar dalam mengeluarkan zakat yaitu 2,5\% dalam artian terbebas dari hutang dan nisbah zakat profesi dipersamakan dengan nisah emas dan juga telah mencapai haul. Apabila hasil yang diperoleh tidak mencapai nishab maka tidak wajib baginya mengeluarkan zakat

\section{Kesimpulan}

1. Sistem penarikan zakat pertanian aktivitas pertanian yang diperoleh dari hasil panen dan telah menjadi kewajiban atas hasil yang didapat dengan meliputi: Tanaman itu dari hasil pertanian berupa (biji-bijian, sayur-sayuran, padi, cengkeh, coklat, kopi), dapat disimpan lama dan telah mencapai nishab 5\% itu untuk tanaman yang diairi dengan alat bantu perairan seperti menggunakan pompa air dan untuk 
tanaman yang diairi dengan tadah hujan maka zakatnya 10\% dan apabila hasil panen yang di dapat tidak mencapai nishab maka tidak wajib mengeluarkan zakat.

2. Sistem penarikan zakat hasil profesi yaitu hasil yang didapat dari pemikiran dan keahlian seseorang serta melalui jenjang pendidikan atau pengetahuan yang tinggi seperti, Advokad, dokter, pengacara, insinyur dan sejenisnya. Dan sistem penarikan zakat hasil profesi meliputi: pendapatan yang diperoleh melebihi dari kebutuhan pokok, mencapai nishab atau kadar dalam mengeluarkan zakat yaitu 2,5\% dalam artian terbebas dari hutang dan nisbah zakat profesi dipersamakan dengan nishab emas dan juga telah mencapai haul. Dengan berlandaskan dua prinsip keadilan yaitu, Pertama, keadilan komulatif yaitu keadilan yang memberikan kepada masing-masing orang apa yang menjadi bagiannya, di mana yang diutamakan adalah objek tertentu yang merupakan hak dari seseorang. Keadilan komutatif berkenaan dengan hubungan antarorang/antarindividu dan keadilan disini lebih menekankan agar prestasinya sama nilainya dengan kontra prestasi. Kedua. Keadilan distributif adalah keadilan yang memberikan kepada masing-masing orang apa yang menjadi haknya, di mana yang menjadi subjek hak adalah individu, sedangkan subjek kewajiban adalah masyarakat. Keadilan distributif berkenaan dengan hubungan antara individu dan masyarakat/negara. Di sini yang ditekankan bukan asas kesamaan/kesetaraan (prestasi sama dengan kontra prestasi). Melainkan, yang ditekankan adalah asas proporsionalitas atau kesebandingan berdasarkan kecakapan, jasa, atau kebutuhan. Keadilan jenis ini berkenaan dengan benda kemasyarakatan seperti jabatan, barang, kehormatan, kebebasan, dan hakhak. 


\section{Wahyuni, Rahman Ambo Masse dan Rukiah}

\section{Daftar Pustaka}

Buku

Al Bukhari, Imam Abdullah Muhammad bin Ismail, Fikih Ekonomi Syariah ,Jakarta: Rajawali Press, 2017.

Antonio, Muhammad Syafi'i. 2001.Bank Syariah Dari Teori Ke Praktek, Jakarta: Gema Insani Press.

Barlinti, Yeni Salman. 2010. Kedudukan Fatwa Dewan Syariah Nasional dalam Sistem Hukum Nasional di Indonesia, Jakarta: Badan Litbang dan Diklat Kementrian Agama.

Basrowi \& Suwandi. ,2009.Memahami Penelitian KualitatifJakarta: PT. Asdi Mahasatya.

Departemen Agama RI. 2002.Al-Qur'an Terjemahnya, Jakarta: CV Darus Sunnah.

Departemen Agama RI. 2002. Al-Qur'an Terjemahnya, Semarang: PT. Karya Toha Putra Semarang.

Departemen Pendidikan Nasional .2005.Kamus Besar Babasa Indonesia Edisi Ke-3Jakarta: Balai Pustaka.

Hamidi, M. Luthfi. 2003. Jejak-jejak Ekonomi Syariah , Jakarta: Senayan Abadi Publishing.

Karim, Helmi. 2002.Figih Muamalah, Jakarta: PT. Raja Grafindo Persada, Cetakan Ketiga.

Kotler, Philip. 2005.Manajemen Pemasaran, Jakarta: PT. Indeks.

Mardani. 2005.Ushul Fiqh, Jakarta: PT Raja Grafindo Persada.

Muhammad. 2008.Metodologi Penelitian Ekonomi Islam Pendekatan Kuantitatif, Jakarta : PT Raja Grafind Persada.

Muttaqiyah, Matsna. 2014. Analisis Penerapan Fatwa Nomor 86/DSN-MUI/XII/ 2012 Tentang Hadiah Dalam Penghimpunan Dana Lembaga Kenangan Syariah di KJKS BINAMA Semarang, UIN Walisongo, Semarang.

Noor, Dr Juliansyah, S.E, M.M. ,Metodologi Penelitian : Skripsi, Tesis, Disertasi, dan Karya Ilmiah (Jakarta: Charisma Putra Kencana)

Rozalinda. 2017. Fikih Ekonomi Syariah , Jakarta: Rajawali Press.

Siregar, Sofyan. 2010.Statistik Deskriptif Untuk Penelitian: Dilengkapi Perbitungan Manual Dan Aplikasi SPSS Versi Versi 17, Edisi I (Cet, 1; Jakarta Rajawali Pers)

Suhendi, Hendi. 2005.Fiqih Muamalah, (Jakarta: PT. Raja Grafindo Persada.

Usman, Nurdin.2002.Konteks Implementasi Berbasis Hukum.

Purnomo ,Rizky.2015.Konsep Hadiah Dalam Akad Wadi'ah Di Bank Syariah (Perspektif Fatwa DSN-MUI No.86/DSN-MUI/XII/2012), UIN Sunan Kalijaga, Yogyakarta.

Sjahdeini. Sutan Remy. 2014. Perbankan Syariah , Jakarta: PT Adhitya Andrebina Agung.

Sugiyono. 2010.Metode Penelitian Pendidikan Pendekatan Kuantitatif, Kualitatif, Dan R \& D, Bandung: Alfabeta, Cet Ke-10

Sutopo , Ariesto Hadi dan Adrianus Arief. 2010. Terampil Mengolah Data Kualitatif Dengan NVIVO, Jakarta: Prenada Media Group.

Ustani, Trisadini P. dan Abd. Shomad. 2015. Transaksi Bank Syariah. Jakarta: Bumi Aksara.

Warita ,Tri.2011.Pemberian Hadiah Pada Program Tabungan Muamalat Berbagi Rejeki Menurut Perspektif Ekonomi Islam (Study Pada PT. Bank. Muamalat Tbk. Cabang Pekanbaru), UIN Sultan Syarif Kasim, Riau. 


\section{Hadis:}

HR. Bukhari dalam Al-Adab Al-Mufrod, no. 594. Hadits ini dihasankan oleh Syaikh Al-Albani dalam AlIrwa', no. 1601.

\section{Wesbite}

Fatwa DSN-MUI No. 86/DSN-MUI/XII/2012. 2018.tentang Hadiab dalam penghimpunan dana lembaga keuangan syariah.https://tafsirq.com/fatwa/dsn-mui/hadiah-dalam-penghimpunan-dana-lembagakeuangan-syariah (diakses pada tanggal 11 april)

http://id.m.Wikipedia.org/wiki/produk (20 April 2017)

https://id.m.wikipedia.org/wiki/Fatwa (21 Mei 2017)

http://www.kbbi.co.id (21 Mei 2017)

http://www.bankmuamalat.co.id/produk-layanan-consumer (07 Maret 2018)

http://www.bankmuamalat.co.id/visi misi (21 Mei 2018)

https://www.scribd.com/doc/84097240/Gambaran-Umum-Bank-Muamalat-Indonesia (21 Mei 2018) 